\title{
Why Do We Have to Have a New Treaty Now?
}

On 25 March 2007, the German Presidency presented a "Declaration on the occasion of the fiftieth anniversary of the signature of the Treaties of Rome". If they look at the end of this document, "the citizens of the European Union" - in whose name it was rather presumptuously written - will discover that they have agreed to place the EU "on a renewed common basis before the European Parliament elections in 2009."

This means trying to agree a new treaty by the end of 2007. The basic idea of the Presidency, supported by the Commission, the Parliament and a considerable number of other actors, seems to be that this should include at least the major institutional changes proposed in the Constitutional Treaty - an elected President of the European Council, a Union Minister of Foreign Affairs (by another name), a reformed system of qualified-majority voting, codecision as "the ordinary legislative procedure", and presumably the common system of legal acts - as well as some innovations in priority policy areas such as climate change and energy.

The Declaration does not give clear reasons to its putative authors as to why a new common basis is necessary. It simply says that, to protect European unification, "we must always renew the political shape of Europe in keeping with the times". The follow-up speeches and debates in the Parliament were permeated by assertions that institutional reform is essential a) because of enlargement and b) to deal with globalisation. In addition, there is an element of face-saving: after all, 18 Member States have ratified the Treaty. Commission President Barroso thus told the Parliament that the failure of the ratification process "leaves a permanent shadow of doubt hanging over the European Union" which has to be removed if the EU is to be convincing.

Yet to stake the Union's credibility on a revised treaty may be to invite another selfinflicted wound. Despite talk of a "constitutional crisis", there is no overwhelming need to do anything. We are not facing political unrest or popular protest. The ability to respond to economic challenges cannot be seriously related to a new treaty. The institutions show no signs of being unable to function at 27. There is a greater danger of causing division or blockage by rushing ahead despite the clear discomfort of several Member States and the manifest doubts of many of those "citizens of the European Union". The burden of proof is therefore on those who want to press ahead with some new political settlement, rather than on those who favour a more pragmatic approach.

Let us ask why we ever thought we wanted a new treaty of "constitutional" dimensions in the first place. Simplification was the starting-point. Everyone could agree that it would be a good thing to "tidy up" the institutional mess left by decades of incrementalism and compromise. The treaty involved specific problem-solving in response to deficiencies in existing arrangements. For example, a single representative and a common External Action Service would boost consistency and effectiveness in external relations. Likewise, the agreement to use the same legal instruments and deepen police and judicial cooperation in criminal matters would help respond to transnational crime. There has also been an objective of consensus-building. The very process of preparing the new treaty was hoped to strengthen political agreement and public support as to the basic rationale and rules of the Union. Above all this, however, has been a clear effort to take advantage of the above for the purpose of what one may call polity-creation. This has taken the form of deliberate politicisation of the debate, as well as the insistence on calling the treaty a "Constitution", having a "Minister" for Foreign Affairs, and incorporating other trappings of a state. 
Taking into account the risks of pushing ahead with a treaty, what do we need to do now? It now seems to be recognised by almost all parties that any new treaty should not use the word "Constitution" and should avoid other terms seen as provocative. However, the issue is not just one of imagery but of serious thinking about the nature of the exercise.

More than 50 years of the Community experience suggest that integration has depended not on public ratification of political visions but on concrete projects which commit the Member States and key actors, and which are perceived as appropriate by citizens. Moreover, institutional questions in themselves just do not positively engage most people. The bottom line should be to achieve a basic consensus between the Member States, and a basic consent on the part of the citizens, as to the reasons and parameters of the Union. It will not help if the EU élite is seen as trying to impose a new and deeper "institutional settlement" for no clear reason, without any time for sustained public debate, and probably with a visible avoidance of further popular consultations by way of referendum. One should not underestimate sensitivities about the consequences for national identity and national interests of absorption into a system of governance involving half a billion people. Greater powers for the European Parliament do not necessarily reassure smaller countries, whose minimal representation there may seem of marginal importance in influencing Parliament or anything else.

Rather than invoking enlargement or globalisation, it would be more effective to try to engage in a sustained debate across Europe about the costs and benefits of particular areas of cooperation. There is a demonstrable gap between the collective will to act, for example in external relations or combating crime, and the possibilities afforded under current institutional arrangements. Climate change and energy could indeed also serve as focal issues. All this could serve as a basis for public and political debate as to the costs and benefits of common action which could in turn contribute to more fundamental discussion about the reasons for European integration.

It would be better not to push ahead with any new treaty at this stage. Some things can be done anyway if we want. The Constitutional Treaty did not in fact propose to change the composition of the first College appointed after entry into force, and its proposal to reduce the number to two-thirds in the future could be implemented without treaty change, under the Nice agreement to have fewer Commissioners than Member States once the EU has 27 members. With regard to police and judicial cooperation in criminal matters, moreover, there is an alternative to treaty change, namely the possibility under Article 42 of the Treaty on European Union for the Council to "communitise" these areas by unanimity, subject to adoption by the Member States in accordance with their respective constitutional requirements.

More importantly, however, it does not matter sufficiently whether other changes requiring treaty reform are adopted now, to justify risking a second failure which would certainly have serious consequences for the credibility of the Union. If a political gesture is to be made, it would be both more prudent and more effective to use other means to engage and convince citizens, perhaps in the form of a pan-European vote on a declaration of principles.

Yet the treaty train seems unstoppable. There seems to be common ground between covert maximalists and declared minimalists that the priority should be to concentrate on substantive issue areas where new forms of common action can be pursued and publicly debated. The challenge is whether political discourse and the proposed institutional changes can be prevented from going beyond what is really "in keeping with the times".

Edward Best

Head of Unit "European Decision-Making", European Institute of Public Administration (EIPA), Maastricht, The Netherlands 